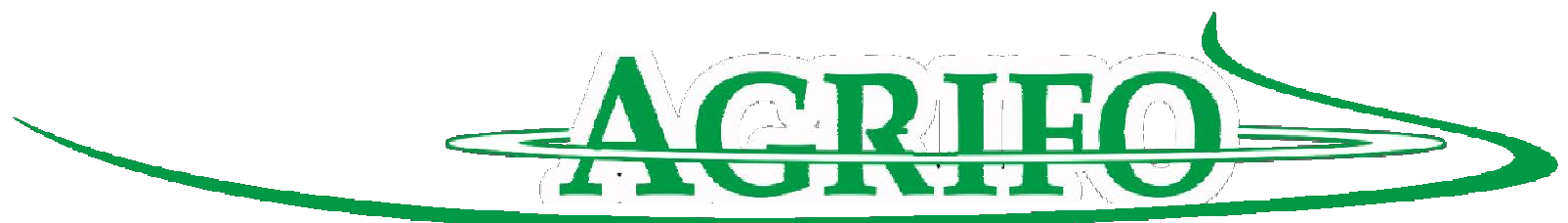

\title{
PENERAPAN TEKNOLOGI PERTANIAN PADA USAHATANI PADI SAWAH DI KECAMATAN MUARA BATU KABUPATEN ACEH UTARA
}

\author{
APPLICATION OF AGRICULTURAL TECHNOLOGY ON THE RICE \\ FARMING IN MUARA BATU SUBDISTRICT NORTH ACEH REGENCY
}

\author{
MARTINA ${ }^{1}$ \\ Email : martina.nafla28@gmail.com
}

\begin{abstract}
ABSTRACK
This study aims to describe the application of agricultural technology on the rice farming in Muara Batu Subdistrict, North Aceh Regency. The method used in this research is survey method by interviewing 30 rice farmers as respondents. Data were analyzed by using qualitative descriptive analysis. The results showed that the type of technology that has been applied, among others: Patterns Planting row legowo, use of superior seeds, making compost, making of vegetable pesticides, utilization of rice thresher machine, and the use of tractors in rice field hijacking. Agricultural technology provides many benefits such as cost-effective, time and labor. The application procedure can be done easily by farmers because it has been accustomed every season planting.
\end{abstract}

Keywords: Agricultural Technology, Rice farming

\section{PENDAHULUAN}

\section{Latar Belakang}

Sampai hari ini pertanian masih merupakan kekuatan ekonomi bagi masyarakat pedesaan dan harapan hidup bagi masyarakat perkotaan. Tidak dapat dibayangkan apa yang terjadi jika sektor pertanian mengalami kegagalan dalam peningkatan produksi padi ("beras"), mungkin akan terjadi kakacauan sosial atau demonstrasi seperti yang terjadi di beberapa daerah dimana masyarakat kota melakukan demonstrasi menuntut penurunan harga beras. Beras merupakan komoditas politik yang sangat strategis karena merupakan bahan pangan pokok bagi lebih dari 95 persen penduduk Indonesia, usahatani padi merupakan penyedia lapangan pekerjaan dan sebagai sumber pendapatan bagi sekitar 21 juta rumah tangga pertanian dan menjadi tolok ukur ketersediaan pangan bagi Indonesia (Suryana, 2002 dalam Saridewi, 2010)

Dalam peningkatan produksi padi, peranan teknologi sangatlah penting karena teknologi merupakan salah satu syarat mutlak pembangunan pertanian yang harus dipenuhi. Teknologi pada usahatani padi sawah yang digunakan petani selama ini masih relatif sederhana, masih banyak menggunakan varietas lokal dan varietas unggul tidak berlabel. Cara tanam tidak beraturan, baik dengan caplak satu arah atau caplak dua arah, sehingga populasi rendah. Penggunaan pupuk sangat tergantung dengan dana yang ada (Miswarti, et. al. 2004).

\footnotetext{
${ }^{1}$ Staf Pengajar di Prodi Agribisnis Fakultas Pertanian Universitas Malikussaleh
} 
Kabupaten Aceh Utara merupakan salah satu Kabupaten yang mayoritas para petaninya merupakan petani padi sawah . Aceh Utara merupakan wilayah sentra produksi padi di provinsi Aceh dengan luas tanam mencapai $75.800 \mathrm{Ha}$ dengan produksi $389.945,41$ ton.(BPS, 2015). Salah satu kecamatan di aceh utara yag memiliki peran yang besar dalam produksi padi adalah Kecamatan Muara Batu yang merupakan wilayah pertanian dengan luas lahan sawah mencapai 2.614 Ha dan mampu memproduksi padi sebanyak 15.122 ton (BPS, 2016). Untuk dapat meningkatkan produksi padi agar tercukupinya kebutuhan pangan daerah tidaklah bisa dilepaskan dari peranan teknologi pertanian terutama pada usaha tani padi sawah sehingga sangat perlu dikaji tentang penerapan teknologi pertanian pada usahatani Padi sawah di Kecamatan Muara Batu Kabupaten Aceh Utara

\section{Tujuan Penelitian}

Adapun tujuan penelitian ini adalah Mendeskripsikan penerapan teknologi pertanian pada usahatani Padi sawah di Kecamatan Muara Batu Kabupaten Aceh Utara.

\section{METODOLOGI PENELITIAN}

\section{Lokasi Penelitian dan Waktu Penelitian}

Penentuan lokasi penelitian dilakukan secara sengaja (purposive sampling) yaitu Kecamatan Muara Batu Kabupaten Aceh Utara, dengan pertimbangan bahwa daerah tersebut merupakan salah satu sentra produksi padi sawah di Kabupaten Aceh Utara. Penelitian dilaksanakan pada bulan Januari 2017.

\section{Populasi dan Sampel}

Populasi dalam penelitian ini adalah seluruh petani padi sawah yang memiliki lahan sawah beririgasi teknis maupun semi teknis dan menanam padi pada musim tanam tahun 2017. Mengingat jumlah populasi yang besar dan memiliki sifat yang homogen maka jumlah sampel yang diambil adalah 30 orang petani.

\section{Data dan metode Pengumpulan Data}

Pada penelitian ini digunakan dua jenis data yaitu data primer yang diperoleh dari responden secara langsung dengan malakukan wawancara kepada petani padi sawah dan data sekunder sebagai data penunjang diperoleh dari studi pustaka dan Badan Pusat Statistik Aceh Utara.

\section{Metode Analisis Data}

Analisa yang dilakukan untuk menjawab tujuan penelitian adalah menggunakan teknik analisis deskriptif kualitatif. Proses analisis data dimulai dengan menelaah seluruh data yang terkumpul melalui panduan wawancara. Dengan variable penelitian yaitu Jenis teknologi pertanian, manfaat, prosedur, dan problema dalam penerapan teknologi pertanian.

\section{Defenisi Operasional Variabel}

1. Jenis teknologi adalah bentuk atau jenis teknologi yang digunakan petani dalam usahatani padi sawah.

2. Manfaat teknologi adalah manfaat yang dirasakan oleh petani dalam penerapan teknologi pertanian dalam usahatani padi sawah.

3. Prosedur adalah tahapan kegiatan petani dalam menerapkan teknologi pada usahatani padi sawah. 
4. Problema adalah masalah yang dirasakan petani dalam penerapan teknologi padi sawah.

\section{HASIL DAN PEMBAHASAN}

\section{Karakteristik Petani Padi Sawah}

Petani yang menjadi responden dalam penelitian ini adalah petani padi sawah yang ada di Kecamatan Muara
Batu. Karakteristik petani meliputi : Umur, Pendidikan, Pengalaman, Jumlah Tanggungan, dan luas lahan.

1. Karakteristik Berdasarkan Umur

Umur petani merupakan salah satu faktor yang berkaitan dengan kemampuan petani dalam mengelola usahataninya. Karakteristik petani berdasarkan umur dapat dilihat pada tabel 1 berikut

Tabel 1. Karakteristik petani berdasarkan umur

\begin{tabular}{|l|l|c|c|}
\hline No. & Umur (Tahun) & Jumlah Petani & Presentase (\%) \\
\hline 1 & Produktif $(15-64)$ & 28 & 93,3 \\
\hline 2 & Tidak Produktif $(>64)$ & 2 & 6,7 \\
\hline \multicolumn{2}{r|}{ Total } & $\mathbf{3 0}$ & $\mathbf{1 0 0}$ \\
\hline
\end{tabular}

Sumber : Data Primer (diolah), 2017

menunjukkan bahwa umur petani padi sawah dalam penelitian ini bervariasi. Umur yang tergolong usia kerja dan produktif menurut UU No. 13 tahun 2003 tentang ketenaga kerjaan menyatakan bahwa usia kerja berkisar antara 15 sampai 64 tahun, artinya kemampuan untuk bekerja lebih baik dari usia lanjut dan anak-anak selain itu dalam usahatani padi sawah kemungkinan untuk meningkatkan hasil masih bisa ditingkatkan bila disertai kemampuan dan usaha. Dari penelitian dapat diketahui petani yang tergolong produktif sebanyak 28 petani, dan 2 petani tergolong sudah tidak produktif lagi.

Umur petani responden dominan pada usia dewasa artinya usahatani padi dominan dilakukan oleh petani pada usia yang produktif. Pada usia ini produktifitas kegiatan usahatani dapat dikerjakan secara optimal dengan curahan tenaga kerja fisik yang tersedia. Umur produktif juga berpengaruh dalam pengambilan keputusa adopsi inovasi pada usahatani padi karena tingkat kemampuan tenaga kerja yang masih memiliki kemampuan yang besar dalam melaksanakan inovasi secara optimal.

2. Karakteristik Berdasarkan Tingkat Pendidikan

Pendidikan merupakan salah satu faktor penting yang dapat mempengaruhi cara petani dalam mengelola usahataninya. Tingkat pendidikan akan berpengaruh terhadap pendapatan dan hasil produksi petani, juga terhadap kemampuan petani dalam menerapkan inovasi baru di bidang pertanian dan membantu petani untuk mengambil keputusan serta dapat memecahkan masalah yang dihadapi petani dalam mengelola usahataninya. Tingkat pendidikan formal yang ditempuh oleh petani responden bervariasi mulai dari tingkat SD, SLTP dan

SLTA. 
Tabel 2. Karakteristik Petani Berdasarkan Tingkat Pendidikan

\begin{tabular}{|l|l|c|c|}
\hline No & $\begin{array}{c}\text { Pendidikan } \\
\text { (Tahun) }\end{array}$ & Jumlah Petani & Presentase (\%) \\
\hline 1 & SD (1-6) & 6 & 20 \\
\hline 2 & SLTP (7-9) & 12 & 40 \\
\hline 3 & SLTA (10-12) & 10 & 33 \\
\hline 4 & S1 (>12) & 2 & 7 \\
\hline \multicolumn{2}{|c|}{ Total } & $\mathbf{3 0}$ & $\mathbf{1 0 0}$ \\
\hline
\end{tabular}

Sumber : Data Primer (diolah), 2017

Berdasarkan Tabel 4 dan gambar

2, tingkat pendidikan formal yang ditempuh petani padi sawah digolongkan atas empat tingkatan yaitu SD, SLTP, SLTA dan S1. Hasil penelitian menunjukkan bahwa persentase terbesar dari tingkat pendidikan petani adalah pada tingkat SLTP ( \%), kemudian diikuti tingkat SLTA, SD dan persentase terendah adalah tingkat S1. Hal tersebut menunjukkan bahwa tingkat pendidikan petani pada wilayah penelitian tergolong rendah.

Pembahasan mengenai tingkat pendidikan dimaksud untuk mengetahui tingkat kemampuan petani dalam mengelola usahataninya. Hal ini terkait dengan berbagai keterbukaan wawasan, pengetahuan, tingkat rasionalitas petani dalam mengelola usahatani dan pengambilan keputusan dalam pengembangan usahataninya. Petani dengan tingkat pendidikan formal rendah cenderung lebih sulit menerima inovasi baru berupa teknologi pertanian pada usahatani padi sawah yang disampaikan. Pada umumnya mereka akan menerima inovasi baru jika telah ada bukti nyata bahwa inovasi tersebut benar-benar menguntungkan untuk usahataninya. Sedangkan petani yang tingkat pendidikan formalnya tinggi cenderung lebih terbuka dalam menerima inovasi baru dan mampu menilai kecocokan inovasi tersebut untuk diterapkan dalam usahataninya.

3. Karakteristik Responden Berdasarkan Pengalaman

Pengalaman seseorang dalam berusahatani berpengaruh dalam menerima teknologi dari luar, petani yang berusia muda akan lebih mudah menerapkan teknologi daripada petani yang lebih tua. Pengalaman oleh petani yang berusia tua diperoleh dari turuntemurun. Oleh karena itu, persepsi tentang tata cara penanaman, pemeliharaan, perawatan, maupun pemanenan secara tradisional dianggap lebih baik daripada teknologi baru. Berikut merupakan tabel tentang lama pengalaman petani dalam melakukan usahatani padi sawah. 
Tabel 3. Karakteristik petani berdasarkan Pengalaman Dalam Melakukan Usahatani Padi Sawah

\begin{tabular}{|c|l|c|c|}
\hline No. & Tingkat Pengalaman & Jumlah Petani & Persentase (\%) \\
\hline 1 & Tinggi $(\geq 15)$ & 11 & 37 \\
\hline 2 & Rendah $(<15$ Tahun $)$ & 19 & 63 \\
\hline \multicolumn{2}{r|}{ Total } & $\mathbf{3 0}$ & $\mathbf{1 0 0}$ \\
\hline
\end{tabular}

Sumber : Data Primer (diolah), 2017

Pengalaman usahatani padi

sawah petani berdasarkan hasil penelitian sebanyak 19 petani memiliki pengalaman lebih dari 15 tahun, hal ini menunjukkan bahwa petani sangat berpengalaman dalam budidaya padi. Pengalaman ini merupakan modal dasar dalam menerapkan teknologi untuk dapat meningkatkan produktivitas padi yang mereka kelola. Menurut Padmowiharjo (1999) pengalaman merupakan pengetahuan yang dialami seseorang dalam kurun waktu yang tidak ditentukan. Pengalaman yang menyenangkan dan memuaskan akan

berdampak positif untuk melanjutkan penerapan teknologi pertanian.

4. Karakteristik Berdasarkan Luas Lahan

Luas lahan usahatani menentukan pendapatan, taraf hidup dan derajat kesejahteraan rumah tangga petani. Luas Penguasaan lahan akan berpengaruh terhadap penerapan teknologi pertanian, karena semakin luas lahan usahatani maka akan semakin tinggi hasil produksi sehingga turut meningkatkan pendapatan petani.Luas lahan Petani Padi sawah pada daerah penelitian dapat dilihat pada tabel 4 berikut.

Tabel 4. Karakteristik Petani Berdasarkan Luas Lahan

\begin{tabular}{|c|l|c|c|}
\hline No. & Luas Lahan (Ha) & Jumlah petani & Persentase(\%) \\
\hline 1 & Kecil $(0,01-1,00)$ & 28 & 93,4 \\
\hline 2 & Sedang $(1,01-2,00)$ & 1 & 3,3 \\
\hline 3 & Besar $(>2)$ & 1 & 3,3 \\
\hline \multicolumn{2}{|c|}{ Total } & $\mathbf{6 0}$ & $\mathbf{1 0 0}$ \\
\hline
\end{tabular}

Sumber : Data Primer (diolah), 2017

Luas lahan usahatani padi yang dimiliki oleh petani sebagian besar (28 petani) memiliki lahan dengan luas antara 0.01-1 Ha. Lahan tersebut kecil sehingga petani sulit untuk mengembangkan usaha taninya secara maksimal. Luas lahan bisa mempengaruhi petani dalam penerapan teknologi pada usahatani padi sawah. Petani yang memiliki lahan yang luas maka petani bisa mencoba inovasi teknologi tersebut pada sebagian kecil

lahannya dan jika berhasil barulah petani melaksanakan inovasi teknologi pada keseluruhan lahan yang mereka miliki. Tetapi, bagi petani yang memiliki lahan yang sempit, sulit untuk menerima inovasi teknologi karena petani takut jika inovasi tersebut mengalami kegagalan. 


\section{Penerapan Teknologi Pada Usahatani Padi Sawah}

\section{Jenis Teknologi}

Dalam perkembangannya, penguasaan teknologi dan inovasi pertanian menjadi salah satu faktor penentu keberhasilan dalam produksi padi sawah. Di Kecamatan Muara Batu, semua petani sudah memanfaatkan teknologi dalam budidaya padi sawah. Jenis teknologi yang sudah diterapkan antara lain : Pola Tanam jajar legowo, penggunaan bibit unggul, pembuatan pupuk kompos, pembuatan pestisida nabati, pemanfaatan mesin perontok padi, dan penggunaan traktor dalam pembajakan sawah.

\section{Manfaat Teknologi}

Jenis teknologi pertama adalah sistem jajar legowo. Manfaat yang dirasakan petani dengan menerapkan pola ini berupa peningkatan jumlah populasi tanaman padi sekitar $30 \%$, hal ini juga dapat meningkatkan jumlah produksi gabah serta mendapatkan bulir gabah yang berkualitas benih. Dengan menerapkan sistem jajar legowo akan menambah kemungkinan barisan tanaman untuk mengalami efek tanaman pinggir dengan memanfaatkan sinar matahari secara optimal bagi tanaman padi yang berada pada barisan pinggir. Semakin banyak intensitas sinar matahari yang mengenai tanaman maka proses metabolism terutama fotosintesis tanaman yang terjadi di daun akan semakin tinggi sehingga akan didapatkan kualitas tanaman yang baik ditinjau dari segi pertumbuhan dan hasil. Hasil atau produksi yang tinggi akan dapat meningkatkan pendapatan petani.

Kedua adalah penggunaan bibit unggul. Di kecamatan Muara Batu, semua petani yang menjadi responden menggunakan bibit unggul. Jenis bibit yang banyak digunakan adalah ciherang yang dibeli dengan harga $\mathrm{Rp}$.
90.000/Kotak. Manfaat yang dirasakan petani adalah dapat menambah produksi gabah karena bibit unggul lebih tahan terhadap hama dan penyakit. Selain itu, masa hidup padi juga lebih cepat. Dalam waktu tiga bulan petani sudah bisa panen sehingga dalam setahun petani bisa melakukan tiga kali musim tanam.

Ketiga pembuatan pupuk kompos dan pestisida nabati. Teknologi yang sudah banyak diterapkan oleh petani adalah membuat pupuk organic seperti pupuk kompos dan pestisida nabati. Penerapan teknologi ini tentu memberikan manfaat seperti penggunaan pupuk kompos dalam pengolahan tanah akan menambah unsure hara dalam tanah tanpa merusak tanah tetapi sebaliknya dapat menyuburkan dan memperbaiki kondisi tanah agar tanah dapat dimanfaatkan secara berkelanjutan. Tanah merupakan tempat hidupnya tanaman, dengan pemberian pupuk kompos selain memperbaiki tanah juga membuat tanaman menjadi hidup lebih subur karena tercukupinya kebutuhan unsure hara bagi tanaman khususnya tanaman padi. Sedangkan pestisida nabati yang dibuat petani dengan bahan utama daun sirsak dapat mengusir hama dari tanaman padi dan pestisida ini tidak bersifat racun sehingga tidak berbahaya bagi kesehatan petani. Selain itu, karena banyaknya dijumpai keong mas di lahan, petani juga dapat membasmi keong mas dengan cara menjadikan keong mas sebagai pupuk organic. Pemanfaat hama keong mas sebagai bahan pupuk organik selain mengemat biaya juga dapat mengatasi/memberantas hama keong tersebut.

Jenis teknologi keempat adalah pemanfaatan mesin perontok padi (thresher). Mesin ini sudah digunakan semua petani responden diwilayah penelitian karena banyak sekali manfaat yang dirasakan petani sehingga 
penggunaan mesin ini cepat diadopsi oleh petani. Manfaat yang dirasakan adalah dapat menghemat waktu, karena akan mempercepat proses perontokan dan kehilangan gabah juga dapat diminimalisir. Mesin perontok juga dapat menghemat biaya karena biaya untuk sewa mesin tidaklah mahal dan tidak menggunakan tenaga kerja yang banyak.

Kelima adalah penggunaan hand traktor. Mesin ini digunakan untuk membajak sawah. Sama seperti alat perontok padi manfaat yang dirasakan petani adalah hemat biaya misalkan luas lahan $2000 \mathrm{~m}^{2}$ petani membayar sewa traktor Rp. 150.000. dengan biaya per rante $\left(400 \mathrm{~m}^{2)}\right.$ sebesar Rp. 30.000,-. Selain itu juga hemat waktu karena dapat mengolah tanah dalam waktu yang relative cepat.

\section{Prosedur Penerapan Teknologi}

Dalam kegiatan budidaya padi sawah, petani menggunakan teknologi mesin seperti handtraktor dan mesin perotok. Tenaga mesin bukan dimiliki langsung oleh petani tetapi mesin yang digunakan adalah mesin sewaan. Prosedur pemanfaatn mesin lebih dipahami oleh operator atau orang yang menyewakan mesin. Seperti handtractor digunakan ketika mengolah tanah baik pada lahan yang luas maupun yang sempit. Petani melihat dan mengawasi operator mesin dalam mengolah tanah sawah hingga selesai. Sehingga cara kerja mesin tidak begitu diketahui oleh petani.

Sedangkan mesin perontok (thereser) digunakan untuk memisahkan gabah dari batangnya. Walaupun disewa, petani sedikit mengetahui cara kerja mesin ini. Mesin biasanya diletakkan di daerah yang rata disertai alas terpal/lembaran plastic di bawah mesin untuk menghindari agar gabah tidak tercecer ketanah dan memudahkan untuk mengumpulkannya, Kemudian penutup mesin di buka dan diperiksa drum, semua gigi perontok, konkaf, lalu bagian dalam mesin dibersihkan dari kotoran dan benda asing yang akan mengganggu dan merusak mesin dan juga berbahaya bagi operator. Setelah itu, drum perontok diputar dengan tangan sampai dirasa tidak ada yang lepas atau bergesekan. Pada saat menggunakan mesin, operator harus berhati-hati dan harus menggunakan masker penutup hidung agar terhindar dari debu yang ditimbulkan sewaktu proses perontokan berlangsung. Kemudian setelah mesin dihidupkan, operator siap melakukan proses perontokkan dan petani selalu mengawasi proses ini.

Selain penggunaan teknologi mesin, petani juga mengunakan teknologi pertanian lainnya seperti penggunaan bibit unggul, pembuatan pupuk kompos, pestisida nabati dan pola tanam jajar legowo. Penggunaan bibit unggul diketahui petani dari penyuluh lapangan dan juga informasi dari petani lainnya yang sudah menerapkannya. Pada mulanya, petani menggunakan bibit turunan yang diperoleh dari panen sebelumnya, tetapi bibit turunan rentan terhadap hama dan penyakit, masa panen yang lama, dan jumlah produksi yang sedikit. Meskipun tidak ada biaya yang dikeluarkan untuk pembelian bibit petani tetap beralih ke penggunaan bibit unggul karena banyaknya masalah yang ditimbulkan oleh bibit turunan. Bibit unggul yang banyak digunakan petani adalah varietas ciherang yang dibeli petani dengan harga Rp.90.000/kotak (5 $\mathrm{Kg})$.

Selain dari penerapan teknologi mesin pada usahatani padi sawah. Petani juga menerapkan tekologi teknis lainnya seperti pembuatan pestisida nabati dari daun sirsak. Hal ini sudah dilakukan oleh petani untuk mengurangi hama tanpa menimbulkan bahaya bagi manusia. 
Untuk cara pembuatan pestisida nabati menggunakan daun sirsak yag ditumbuk sampai halus. Hasil tumbukan direndam dengan menggunakan air dan diberi deterjen kemudian diaduk higga rata, dan diamkan selama 2 hari. Setelah itu, disaring dan disimpan dalam derijen. Ketika petani akan menggunakannya, larutan pestisda yang sudah jadi diambil 1liter dan dicampur kedalam 10 liter air biasa. Pada saat petani mengolah sawah, petani memberikan pupuk kompos dari jerami yang dibuat sendiri oleh petani. Hal ini rutin dilakukan petani setiap kali panen, sisa jerami dijadikan pupuk kompos. Cara pembuatannya dianggap mudah oleh petani yaitu menyiapkan jerami sekitar $100 \mathrm{~kg}$, kemudian petani membuat lubang pengomposan dengan ukuran $1,5 \mathrm{~m} \quad \mathrm{x} \quad 1 \mathrm{~m} \quad \mathrm{x} \quad 1 \mathrm{~m}$. jerami dimasukkan kedalam lubang pengomposan dan jika sudah sekitar $20 \mathrm{~cm}$ ketebalannyadisiram dengan air sekitar satu ember. Kemudian ditambah mikroba pengompos seperti EM4 cair.langkah tersebut dilakukan berulang-ulang sampai jerami habis dan tutup lubang pengompos dengan plastic berwarna gelap/mulsa.

Pola tanam jajar legowo juga diterapkan petani di Kecamatan Muara Batu. Secara umum jarak tanam yang dilakukan petani adalah 20 x $20 \mathrm{~cm}$ dengan jenis varietas IR-64 seperti ciherang. Ada beberapa tipe sistem jajar legowo yang digunakan yang dipercaya petani dapat meningkatkan produksi gabah dan menghasilkan gabah yang berkualitas benih yaitu tipe jajar legowo 2:1.

Jajar legowo 2:1 adalah cara tanam padi dimana setiap dua baris tanaman diselingi oleh satu barisan kosong yang memiliki jaraj dua kali dari jarak tanam antar baris sedangkan jarak tanam dalam barisan adalah setengah kali jarak tanam antar barisan. Dengan sistem jajar legowo 2:1 seluruh tanaman dikondisikan seolah-olah menjadi tanaman pinggir

\section{Problema Dalam Penerapan Teknologi \\ Dalam penerapan teknologi} pertanian, meskipun banyak manfaat yang dirasakan petani tetapi tidak akan lepas dari berbagai masalah. Seperti dalam penggunaan bibit unggul dengan varietas ciherang, sudah lama diterapkan oleh petani dan varietas ini sudah mulai rentan terhadap hama dan penyakit sehingga petani banyak mengeluarkan biaya untuk penyemprotan. Dan kemungkinan besar petani menyatakan walaupun masih menggunakan bibit unggul tetapi dengan varietas yang berbeda. Kemudian dalam penggunaan mesin, petani masih memikirkan tenaga kerja. Kekhawatiran petani dalam menerapkan teknologi mesin akan mengurangi tenaga kerja sehingga buruh tani banyak yang menganggur dan berpendapatan minim. Seperti mesin pemotong, walaupun sudah diinformasikan oleh penyuluh, sekitar 22 petani menyatakan tidak mau menggunakan mesin pemotong.

Tidak semua petani yang memanfaatkan jerami untuk dijadikan pupuk kompos. Sebanyak 17 petani tidak yang sudah menerapkan pembuatan pupuk kompos, sedangkan petani lainnya masih banyak yang membakar jerami setelah panen padahal dengan membakar jerami akan mencemari udara dan dekatnya jarak pandang. Kekhawatiran petani ketika melakukan usahatani padi adalah ketakutan jika harga gabah murah pada saat panen yang melimpah.

KESIMPULAN

Dalam kegiatan usahatani padi di Kecamatan Muara Batu sudah memanfaatkan teknologi pertanian. Jenis teknologi yang diterapkan pada 
usahatani padi sawah adalah Pola Tanam jajar legowo, penggunaan bibit unggul, pembuatan pupuk kompos, pembuatan pestisida nabati, pemanfaatan mesin perontok padi, dan penggunaan traktor dalam pembajakan sawah. Teknologi pertanian memberikan banyak manfaat seperti hemat biaya, waktu dan tenaga kerja. Prosedur penerapannya dapat dilakukan dengan mudah oleh petani karena hal tersebut sudah dibiasakan setiap musim tanam.

\section{DAFTAR PUSTAKA}

Badan Pusat Statistik. 2015. Aceh Utara Dalam Angka Tahun 2014. BPS Aceh Utara.

Badan Pusat Statistik. 2016. Kecamatan Muara Batu Dalam Angka Tahun 2015. BPS Aceh Utara.
Misrawati, Ishak Manti, Artuti, dan Hidayatullah,(2004).

Peningkatan Produksi padi Sawah melalui Teknologi Sistem Tanam Legowo.Prosiding Seminar Hasil Penelitian dan Pengkajian Teknologi Pertanian, Bengkulu.

Saridewi,Tri Ratna dan Siregar,Amelia Nani. 2010. Hubungan Antara Peran Penyuluh Dan Adopsi Teknologi Oleh Petani Terhadap Peningkatan Produksi Padi Di Kabupaten Tasikmalaya. Jurnal Penyuluhan Pertanian Vol. 5 No. 1, Mei 2010

Padmowihardjo, S . 1999. Psikologi Belajar Mengajar. Jakarta: Universitas Terbuka. 